\title{
Emerging Issues in Business Education: \\ A Panacea for Effective Utilization and Application of ICTS as a Tool in Business Education in Nigerian Universities
}

\author{
Ezeani Nneka Salome (Ph.D) \\ E-mail: Salonneka@yahoo.com (08035726244) \\ Department of Educational Foundation and Management, \\ Ekiti State University, Ado-Ekiti, Nigerian
}

\author{
Ishaq Ahmed Mohammed \\ E-mail: miishaqmashaq@yahoo.com \\ Department: Business Education (08069692552) \\ Federal College of Education (Technical), Gombe
}

\begin{abstract}
The business education programme has experienced unprecedented technological changes in the recent years. The new trend in ICTs place greater responsibilities on business educators. If business educators must be the master of the skills and knowledge of ICTs he teaches, he must be retrained regularly as to adapt to the technological changes in education industries. This study seeks to find the extent of utilization and application of ICTs tools in teaching and learning of business education courses in Nigerian universities. A survey design was employed for the study. The population for the study consists of 100 business educators in the universities located in South-East (Abia, Anambra, Enugu, Ebonyi and Imo States). There was no sample; hence the population was very few. A questionnaire containing 5-point Likert type of scale was used. The data generated was analyzed using frequency count and z-test statistics (for research questions and hypothesis respectively), the study reveals that there was no significant difference in the mean scores of male and female business educators regarding the strategies, ICT tools/facilities and problems hindering the teaching and learning of business education courses in the Nigerian Universities, so gender is not a barrier at all. It recommends that the Nigerian government should provide enough capital for the procurement and maintenance of ICT tools.
\end{abstract}

Keywords: Business education, ICT tools, Business Educators, Training and Development Tool, Utilization and Application. 


\section{Introduction}

Business Education is one of the aspects of vocational education that focuses on skills and knowledge acquisition for the recipients. The goal of business education according to Anao, (1986) is the production of manpower that possesses the requisite knowledge, skill and attitude for harnessing other resources and brings them into co-operative relationships yielding goods and services demanded by society for satisfaction of other wants and needs. However, business education been skill acquiring discipline must inculcate in the recipients to have knowledge and skill of ICT.

The premise that ICT is essential for bringing changes to classroom teaching and learning in educational systems around the world are under increasing pressure to the society and the world at large. The acronym for ICT means Information and Communication Technologies. Mandara (2012) sees ICT as those technologies that are used for accessing, promoting globalization and knowledge, data and skills from which education can benefit substantially. According to Law, Pelgurum and Plomp (2008), these data and skills include the ability to become lifelong learners within a context of collaborative inquiry and the ability and learn from experts and peers in a connected global community.

As the access to information continues to grow exponentially, business education remains more channels for the transmission of prescribed set of information from teachers to students over a fixed period of time. (Odiari, 1987). Buttressing the above view, Kwacha (2007) affirms that the use of educational systems are increasingly obliged to use ICT hence, it provides information and knowledge for learners as well as exercising abilities and skills needed in the labour market. The labour market demands a work force that can use technology as a means to increase productivity and creativity. This includes networks such as fixed wireless and satellite, broadcasting networks, telecommunications, and applications like the internet, intranet, database management systems and multi-media tools. To Alibi (2004), these skills include identifying reliable sources of information, effectively accessing these sources of information, synthesizing and communicating that information to colleagues and associates. Information is very vital for 
under-graduate learning, teaching, research and publishing, and as well as in carrying out class assignments and home work. Hawkins (1998) sees information as essential for effective means for processing and transmitting teaching-learning.

The evolution of ICT in the universities environment brought a lot of changes in the teaching-learning situations. This new changes encourages distance learning and also achieve a closer collaboration between different universities and also pave way for a new pedagogical approach where there is unparalleled ability to spread knowledge and disseminate information (Nwosu, and Ogobomo 2012). The authors further attest that;

The pace of change brought about by new technologies has had a significant effect on the way people live, work and play worldwide. New and emerging technologies challenges traditional process of information use, dissemination and the ways information is managed. Easy worldwide communication provides instant access to a vast array of data, challenge assimilation and assessment skills, rapid communication plus increased access to ICT at home, work and in education establishment.

ICTs in all developed countries have the potential for increasing access to and improving the relevance and quality of education by facilitating the acquisition and absorption of knowledge, to enhance educational systems, improve policy formulation and execution and widen opportunities for business. With ICT, according to Sardka and Sader (30023), students can have access to lessons presented with soft wares, simulate situations, build their own knowledge, improve their knowledge base, work with peers and experts across the globe, explore authentic issues, select the mode by prefer and work at their own pace. However, when ICT are appropriately utilized, this will assist business education students in accessing information, strengthen the need for increasing digital learning, and raise business education quality and standard, by assisting the students in teaching and learning process connected to real life situation. 
Though ICT has been the order of the day in educational environment, yet, there still hunches in utilizing ICT in all facets of human endeavors. In view of Mandara (2012), the utilization of ICT in facilitating the knowledge acquisition and dissemination within and between variables had been such that human input is reduced to the barest minimum with supersonic speed. Therefore, utilization of teaching and learning of business education as aspect of vocational education involves the use of technology, teachers' competences, technical support, huge amount of capital for the purchase of equipment/facilities. From the preliminary studies conducted in the Nigerian universities offering business education programme, it seems that the graduates of this programme were not adequately exposed for ICT skills expected in teaching/learning environment. Thereby these students sought for an extra ICT training in and outside the school or upon their graduation. These result in patronizing and enhancing the business centers/cyber cafes. The poor performance of business education students in the field of ICT could be as a result of teachers' non utilization and application of appropriate information and communication technologies tools or unavailability of ICT tools in the inculcation of business education courses. It is based on the above views that the study intend to examine the extent of utilization and application of ICT tools in delivering business education courses in the Nigerian universities.

The main objective of this study is to examine the extent of utilization and application of ICT in teachings of business education courses in Nigerian universities. Specifically, the study sought to:

1. Identify the strategies for effective utilization and application of ICTs in the teaching and learning of business education courses in the Nigerian universities.

2. Find out the extent of utilization of ICT tool in the teaching and learning of business education courses in the Nigerian universities.

3. Determine the problem that hinders the effective utilization and application of ICT in the teaching of business education courses in the Nigerian universities. 
The study sought to answer the following questions:

1. What are the strategies for effective utilization and application of ICTs in the teaching and learning of business education courses in the Nigerian universities?

2. To what extent are ICT tools/facilities utilized in the teaching and learning of business education courses in the universities of Nigerian.

3. What are the problem that hinders the effective utilization and application of ICT in the teaching and learning of business education courses in the Nigerian universities?

\section{Hypotheses}

The following hypotheses were formulated for the study:

$\mathrm{H}_{\mathrm{O} 1}$ : There was no significant difference between the mean scores of male and female business education teachers on the strategies for effective utilization and application for ICTs in the teaching and learning of business education courses in the Nigerian universities.

$\mathrm{H}_{\mathrm{O} 2}$ : $\quad$ Female and male business education teachers do not differ in their mean scores on the extent of utilization of ICT tools in the teaching and learning of business education courses in the Nigerian universities.

$\mathrm{H}_{\mathrm{O} 3}$ : The mean scores of male and female business education teachers do not differ significantly on the problem that hinders the effective utilization and application of ICTs in the teaching and learning of business education courses in the Nigerian universities.

\section{Review of Literature}

\section{Training and Development}

Year after year, students are admitted into the universities or other tertiary institutions. On this ground, it is expected that the students are acquainted with the aim of education as specified as specified in the National Policy, as well as fulfilling the goal for tertiary institutions in Nigerian. According to FGN (2004), technical and vocational education referred to those aspects of the educational process that involves the general education, the study of technologies and related sciences and 
acquisition of practical skills, attitude, promote national and international understanding and interaction, exposure to relevant future working environment respectively. When all these objectives were achieved, one may agree that there are possible ways of solving problems that are obvious in the economy of Nigerian and in the world today.

Nzotta, (2002) defines training as a mixture of teaching and practices carried out in other to attain a desired standard of behaviour efficiency and effectiveness. On the other hand, Egungu (2001) sees training as a way of building capacity into people and adding of values in area of knowledge, skills and attitude.

From the above definitions, training means the acquisition of skills, attitude, instruction and practical in order to ensure a remarkable influence on behaviour. Also, it means solving educational objectives through the act of doing, attempting, reflecting on experience and familiarizing in the act for the purpose of development and required skills.

Development according to Koonz and Weihrich (1990), refers to a system integration and planned approach to improve the effectiveness of an individual. To Nzotta (2002), development includes the progress made by a person which may involve intellectual or conceptual growth along with practical performance. This shows that development has to be well organized, planned and articulated idea for change, upgrading, application and expression. Development enhances the trainee or learners in achieving optimum potentials and capabilities in business education before the end of the programme, and utilized to actual situations at either local or foreign scenes.

Business education deals with empowerment necessary to meet business challenges in a dynamic business world or society. It offers recipients the ability to cope with emerging changes in education, and in business where the person is expected to manifest all the skills acquired while in training. Therefore, business education is planned for training and developing recipients to expose them in the field of business, and as a 
professional, consequently, expanding the way for imparting competences for economic development of the society.

\section{Empirical studies}

In the study of Aigbepue (2011) on the topic titled, Information Technology: a panacea for poverty alleviation, the study sought to juxtapose the revitalization of vocational and technical education which provides theoretical and practical skills necessary for self-reliance with the aid of information technology. The study revealed that vocational education was viewed as an indisputable means of reducing poverty in the society by imparting the relevant vocational and ICT skills, knowledge and abilities required for work. The study recommends that there should be provision of dedicated and special intervention funding as well as improved awareness campaign of the acquisition and development of entrepreneurial skills.

In another study carried out by Nwosu and Ogbomo (2012) on ICT Education: a catalyst for effective use of information, aimed at ascertaining how ICT could be a catalyst to effective use of information by under graduates. The study employed a descriptive survey method using the expost-facto design. The population for this study consists of 212 final year undergraduates of the department of library and information science, Delta State University, Abraka. Questionnaire was used for data collection. Sample size of 84 students was drawn from the population out of which 60 copies of the questionnaire retrieved. The data collected were analyzed using descriptive statistics frequency and percentages. The study revealed that there is no single policy set aside for planning policies and programmes to introduce ICT in the use of information to undergraduates. Also, problems associated with the ICT for educational activities should be addressed for proper implementation of ICTs in education. The study therefore, recommended that issues and challenges of ICTs in education should be given urgent/adequate attention.

Still, in a study carried out by Mandara (2012) titled utilization of information and communication technologies (ICT) in the teaching of office education for quality assurance of office education graduates in 
Adamawa State tertiary institutions, sought to find out the extent of application of ICTs in teaching and learning of office education courses in order to ensure the quality of office education graduates in Adamawa State of Nigeria. A survey design was adopted for the study. The area of the study was tertiary institutions in Adamawa. The population of the study 15 respondents, comprising teachers of business education programme. The entire population was studied. A structured questionnaire consisting of 20 items was used. The instrument was validated by three experts and 5-point Likert type of scale was adopted. The study found that the teachers of business education office option are not making adequate and effectively use of ICT tools and facilities in learning of office education due to its unavailability. The study recommended that teachers should be encouraged to make use of ICT tools.

It was observed that out of the these three studies, two utilized questionnaire as a means of data collection and a 5-point Likert type of scale was adopted by Mandara. The two studies also analyzed the data generated using frequency count, percentages, mean and standard deviation, respectively. In the present study, the entire population were studied, 5-point Likert point of scale were also employed. The questionnaire were used for data collection generated by the study were analyzed using the frequency count, mean scores and z-test. So, the three studies and the present studies are similar but differ in the use of z-test.

\section{Methodology}

A survey research design was employed for the study. The study covers 100 business educators in the Nigerian universities that offers business education programme in the South-East (Abia, Anambra, Enugu, Ebonyi and Imo states). Because the population was very few and manageable, all were studies and there was no sample. The major instrument for the study was a questionnaire constructed by the researchers. The instrument to answer research question was structured using of 5-point Likert type of scale. Thus, question 2 using 5-point scale of:

5 very highly utilized (VHU), 4 highly utilized (HU), 3 utilized (U), 2 moderately utilized (MU) and 1 not utilized (NU). While questions 1 and 
3 utilized 5-points likerts response scale: 5 strongly agree, 4 agree (A), 3 neutral, 2 disagree (DA) and 1 strongly Disagree (SD). Any item with a mean value of 3.00 and above falls under agree and utilized, while any item that falls below the mean value of 3.00 full under disagree and not utilized. Data generated were analyzed using frequency count and mean scores. While Z-test was used for the 3 hypotheses.

\section{Discussion and Results}

\section{Results}

\section{Research Question 1}

Table 1: Frequency and Mean Scores of Business Education Teachers on the Strategies

For Effective Utilization and Application of ICTs in Teaching/Learning of Business Education Courses in Nigeria Universities

\section{FREQUENCY}

S/N Strategies for Effective ICTs

1. Teachers have negative attitude towards the adoption and utilization of ICT

2. Government funding 40 and procurement for 40 ICT tools

3. Proper supervision of 30 teachers on ICT

4. Provision of qualifiec 20 mechanical personne 20 for proper maintenance of ICT tools

5. Exposing the general 10 public on the benefits 10 of ICT

6. Motivation of business teachers
SA

A N

DA

(4) (3) (2)

50

50

30

30

$\begin{array}{ll}10 & 5 \\ 10 & 5\end{array}$

SD \% TOTAL MEAN

(1)

100

$5 \%$ 
7. Training of business 50 teachers on periodic 50
basis $\begin{array}{lllll}30 & - & 10 & 10 & 100\end{array}$ 4.00

8. Provision of ICT $\quad 40 \quad 50 \quad 10 \quad 5 \quad 5 \quad 5 \quad 100$ tools, facilities and $\begin{array}{llllll}40 & 50 & 10 & 5 & 5 & \%\end{array}$ infrastructure

9. Adequate power supply

$60 \quad 20$

$60 \quad 20 \quad 5$

10. Government $20 \quad 60$ intervention into ICT 20 school curriculum

11. Teachers enhanced salaries

20

20

12. In collaboration of

20
public sector in the 20 provision of ICT tools

13. Scheduling of computer time

50

$$
30-
$$

$$
10
$$

10

$30-10$

$10 \%$

14. Provision of software 40

$\begin{array}{lll}30 & 20 & 10\end{array}$
copies

$30 \quad 20$

- $\%$

15. Provision of adequat 50

20 -

telephone lines

50

$20 \quad-\quad 15 \quad 15 \quad \%$

20

10

$15 \quad 100$

16. Integration of ICT tc 40 instruction 40 $40 \quad 10$

$10 \quad 100$

$\begin{array}{lllll}40 & 10 & - & 10 & \%\end{array}$

17. Provision of $\begin{array}{lll}10 & 30 & 30\end{array}$

15

$15 \quad 100$ sufficient peripherals

$\begin{array}{lll}30 & 30 & 15\end{array}$

$15 \%$

18. Provision of enough 40 supervision staff

40

$40 \quad 10 \quad-$

$10 \quad 100$

$\begin{array}{lllll}40 & 10 & - & 10 & \%\end{array}$

19. Provision of enough 60 computers

205

205

20. Provision of enough 40 simultaneous access 40

$10 \quad 10$

123

100

$\begin{array}{lllll}10 & 10 & 30 & 10 & \%\end{array}$

100

Sources: Field survey 2012

Result in table 1 above indicate that 19 items have mean values of 3.00 and above which is the stipulated positive decision rule while one of the items attracted mean value of 2.90 showing that teacher of business education programme were not motivated at all. Therefore, these 19 items were regarded as the strategies for effective utilization and application of 
ICTs in teaching/learning of business education courses in Nigerian universities.

\section{Research Question 2}

Table 2: Frequency and Mean Scores of Business Teachers on the Utilization of ICT Tools/Facilities in Teaching and Learning of Business Education Courses in Nigerian Universities

\section{FREQUENCY}

\section{S/N ICT TOOLS}

1. Internet facilities

2. Overhead projector

3. Networking

4. Generator

5. Light Pen

6. Fax Machine

7. World Wide Web (www)

8. Video Cassette recorder

9. Video projectors

10. CD-ROM

11. Computer Assistant Instruction (CAI)

12. Telephone lines

13. Date Management Packages

14. E-mail

15. Computer Laboratory

\section{SA A N DA SD \%}

(5)

(4)

(3) (2)

(2)

(1) $\begin{array}{lllll}50 & 30 & 5 & 5 & 10\end{array}$

$\begin{array}{llllll}50 & 30 & 5 & 5 & 10 & \%\end{array}$

$\begin{array}{llllll}40 & 20 & 10 & 20 & 10 & 100\end{array}$

$\begin{array}{llllll}40 & 20 & 10 & 20 & 10 & \%\end{array}$

$2080-\quad-\quad-\quad 100$

$2080-\quad-\quad-\%$

$\begin{array}{llll}50 & 30 & 10 & 5\end{array}$

$\begin{array}{lllll}50 & 30 & 10 & 5 & 5\end{array}$

$\begin{array}{lllll}30 & 40 & 20 & 5 & 5\end{array}$

$\begin{array}{lllll}30 & 40 & 20 & 5 & 5\end{array}$

$\begin{array}{llllll}30 & 30 & 10 & 20 & 10 & 100\end{array}$

$\begin{array}{llllll}30 & 30 & 10 & 20 & 10 & \%\end{array}$

$40 \quad 50 \quad 10-\quad-\quad 100$

$40 \quad 50 \quad 10-\quad-\%$

$\begin{array}{llll}30 & 30 & 20 & 10\end{array}$

$\begin{array}{llll}30 & 30 & 20 & 10\end{array}$

$\begin{array}{lllll}50 & 20 & 10 & 20 & -\end{array}$

$\begin{array}{lllll}50 & 20 & 10 & 20 & -\end{array}$

$\begin{array}{lllll}30 & 40 & 20 & 5 & 5\end{array}$

$\begin{array}{lllll}30 & 40 & 20 & 5 & 5\end{array}$

$\begin{array}{lllll}40 & 30 & 10 & 10 & 10\end{array}$

$10 \quad 100$

$\begin{array}{llllll}40 & 30 & 10 & 10 & 10 & \%\end{array}$

$\begin{array}{llll}50 & 30 & 5 & 5\end{array}$

$\begin{array}{llllll}50 & 30 & 5 & 5 & 10 & \%\end{array}$

$\begin{array}{lllll}40 & 30 & 10 & 10 & 10\end{array}$

$\begin{array}{llll}40 & 30 & 10 & 10\end{array}$

$\begin{array}{lllll}50 & 30 & - & 10 & 10\end{array}$

$50 \quad 30-10$

$30 \quad 40 \quad 15$ -
10

10

$10 \%$

$10 \%$

100

3.80

4.00

3.70 


\begin{tabular}{|c|c|c|c|c|c|c|c|c|c|}
\hline & & 30 & 40 & 15 & & 15 & $\%$ & & \\
\hline \multirow[t]{2}{*}{16.} & Application Software & 10 & 30 & 40 & 10 & 10 & & 100 & 3.20 \\
\hline & & 10 & 30 & 40 & 10 & 10 & $\%$ & & \\
\hline \multirow[t]{2}{*}{17.} & Electronic scanners & 30 & 30 & 20 & 10 & 10 & & 100 & 3.60 \\
\hline & & 30 & 30 & 20 & 10 & 10 & $\%$ & & \\
\hline \multirow[t]{2}{*}{18.} & Video and Audio & 50 & 25 & 20 & - & 5 & & 100 & 4.15 \\
\hline & Conference Equipment & 50 & 25 & 20 & - & 5 & $\%$ & & \\
\hline \multirow[t]{2}{*}{19.} & Electronic chalk board & 25 & 20 & 30 & 15 & 10 & & 100 & 3.55 \\
\hline & Application & 25 & 20 & 30 & 15 & 10 & $\%$ & & \\
\hline \multirow[t]{2}{*}{20.} & Stencil Electronic & 20 & 40 & 20 & 20 & - & & 100 & 3.60 \\
\hline & Machine & 20 & 40 & 20 & 20 & - & $\%$ & & \\
\hline \multirow[t]{2}{*}{21.} & Computer Printer & 30 & 50 & 20 & - & - & & 100 & 4.10 \\
\hline & & 30 & 50 & 20 & - & - & $\%$ & & \\
\hline
\end{tabular}

Source: Field Survey 2012

In Table 2 above, the 21 items were rated the mean of 3.00 and above showing that these items were not utilized at all in the teaching and learning of business education courses.

\section{Research Question 3}

Table 3: Frequency and Mean Scores of Business Educators on the Problems that Hinders the Effective Utilization and Application of ICTs in the Teaching and Learning ofBusiness Education in the Nigerian Universities

\section{FREQUENCI}

\section{S/N PROBLEMS IN UTILIZATION \& APPLICATION OF \\ ICT TOOLS}

\section{SA}

(5)

1. Lack of fund 50

50

2. Equipment/facilities 40 highly expensive $\quad 40$

3. Inconsistent electric 40 power supply $\quad 40$

4. Shortage of 50 equipment/facilities 50 (Workshops and
A N DA SD \% TOTAI MEAN

(4) (3) (2) (1) 
laboratory)

5. Insufficient teacher 30 time 30

6. Insufficient 20

Peripherals 20

7. Societies negative 30 attitude towards ICT 30

8. Lack of mechanical 50 manpower (Technica 50 Assistance)

9. Government non- 40 chalant attitude $\quad 40$ towards ICTs curriculum in schools

10. Poor teaching 40 strategy (Method) 40

11. Poor incentive of 30 Business Education 30

12. Lack of training 40 programme for $\quad 40$ business education teachers

13. Bad attitude of schoo 40 management in the 40 teaching and application of ICTs

14. Insufficient number 48 of computers $\quad 48$

15. Difficult to integrate 40 ICT to instruction $\quad 40$

16. Scheduling computer 30 time $\quad 30$

17. Lack of qualified IC] 40 personnel (Teachers) 40

18. Insufficient copies of 50 software $\quad 50$

19. Not enough 30 supervision of staff 30

20. Not enough 30 simultaneous access 30

$\begin{array}{lllllll}50 & 10 & 5 & 5 & & 100 & 3.95 \\ 50 & 10 & 5 & 5 & \% & & \\ 30 & 10 & 10 & 30 & & 100 & 3.00 \\ 30 & 10 & 10 & 30 & \% & & \\ 20 & 30 & 10 & 10 & & 100 & 3.50 \\ 20 & 30 & 10 & 10 & \% & & \\ 40 & 10 & - & - & & 100 & 4.40 \\ 40 & 10 & - & - & \% & & \\ & & & & & & \\ 30 & 10 & 20 & - & & 100 & 3.90 \\ 30 & 10 & 20 & - & \% & & \end{array}$

$\begin{array}{lllll}50-\quad & - & 10 & 100 & 4.10\end{array}$

50 - $-10 \%$

$\begin{array}{llllll}20 & 10 & 30 & 10 & 100 & 3.30\end{array}$

$\begin{array}{lllll}20 & 10 & 30 & 10 & \%\end{array}$

$40-10 \quad 10 \quad 100 \quad 3.90$

$40-10 \quad 10 \%$

$\begin{array}{llllll}30 & 10 & 10 & 10 & 100 & 3.80\end{array}$

$\begin{array}{lllll}30 & 10 & 10 & 10 & \%\end{array}$

$\begin{array}{llllll}32 & 10 & 10 & - & 100 & 4.18\end{array}$

$32 \quad 10 \quad 10-\%$

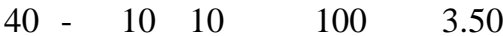

$40-10 \quad 10 \%$

$\begin{array}{llllll}30 & 15 & 5 & 20 & 100 & 3.45\end{array}$

$\begin{array}{lllll}30 & 15 & 5 & 20 & \%\end{array}$

$\begin{array}{lllll}50- & - & 10 & 100 & 3.60\end{array}$

$50-\quad-10 \%$

$\begin{array}{llllll}30 & 10 & 5 & 5 & 100 & 4.15\end{array}$

$\begin{array}{lllll}30 & 10 & 5 & 5 & \%\end{array}$

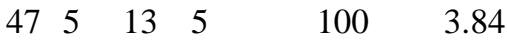

$\begin{array}{lllllll}47 & 5 & 13 & 5 & \% & & \\ 20 & 20 & 10 & 20 & & 100 & 3.30\end{array}$

$\begin{array}{lllll}20 & 20 & 10 & 20 & \%\end{array}$ 
21. In equate telephone 50 lines

50

$\begin{array}{llllll}30 & 10 & 5 & 5 & & 100 \\ 30 & 10 & 5 & 5 & \%\end{array}$

Source: Field survey, 2012

With a mean rating of 3.00 and above, all the 21 items were identified as the problems hindering the successful utilization and application of ICTs in delivering of business education courses in the Nigerian universities.

\section{HYPOTHESES}

\section{Hypothesis 1}

Table 4: Results of Z-Test Difference between Mean Responses of Male and Female Business Education Teachers and Application of ICTs in the Teaching and Learning of Business Education in the Nigerian Universities

$\begin{array}{llllllll}\begin{array}{l}\text { Business } \\ \text { Teachers }\end{array} & \begin{array}{l}\text { Sample } \\ \text { Size }\end{array} & \begin{array}{l}\text { Mean } \\ (\mathbf{X})\end{array} & \begin{array}{l}\text { Standard Standard } \\ \text { Deviation }\end{array} & \begin{array}{l}\text { Z-test } \\ \text { Value }\end{array} & \begin{array}{l}\text { Significant } \\ \text { probability }\end{array} & \text { Decisions } \\ \text { Male } & 45 & 2.82 & 0.978 & 0.078 & & & \\ \text { Female } & 55 & 2.80 & 0.965 & 0.065 & & & \text { NS }\end{array}$

The Z-test value is -0.131 with a significant probability of 0.890 . The Z-test score is not significant at 0.05 level since 0.890 is greater than 0.05 . This means that there is no significant difference in the ratings of male/female business education teachers on the effective strategies for utilization and application of ICTs in the teaching and learning of business education courses in the Nigerian universities. Therefore, the null hypothesis is accepted. 


\section{Hypothesis 2}

Table 5: Results of Hypothesis of Z-Test Difference between Mean Scores of Female and Male Business Education Teachers on Extent of Utilization of ICT Tools in the Teaching and Learning of Business Education Courses in The Nigerian Universities

$\begin{array}{llllllll}\begin{array}{l}\text { Business } \\ \text { Teachers }\end{array} & \begin{array}{l}\text { Sample } \\ \text { Size }\end{array} & \begin{array}{l}\text { Mean } \\ (\mathbf{X})\end{array} & \begin{array}{l}\text { Standard Standard Z-test } \\ \text { Deviation }\end{array} & \begin{array}{l}\text { Significant } \\ \text { probability }\end{array} & \text { Decisions } \\ \text { Value } & & & & & & & \\ \text { Male } & 55 & 2.78 & 1.10 & 0.124 & & & \\ \text { Female } & 45 & 2.69 & 0.73 & 0.056 & & & \end{array}$

The Z-test score value is 0.354 with a significant probability of 0.723 . The Z-test is not significant at 0.05 level since 0.713 is greater than 0.05 . It means that there is no significant difference in the ratings of male/female business education teachers on the extent of utilization of ICT tools in the teaching and learning of business education courses. The null hypothesis is therefore, accepted.

\section{Hypothesis 3}

Table 6: Results of Z-Test Difference between the Mean Scores of Male and Female Business Education Teachers on the Problems that Hinders the Effective Utilization and Application of ICTS in the Teaching and Learning of Business Education Courses in the Nigerian Universities

Business Sample Mean Standard Standard Z-test Significant Teachers size (X) Deviation Error Value probability Decisions

$\begin{array}{lrllllll}\text { Male } & 45 & 2.82 & 0.983 & 0.108 & & & \\ \text { Female } & 55 & 2.76 & 0.02 & 0.081 & & & \text { NS }\end{array}$

The date presented on table 6 showed that with the Z-test value of -0.93 and significant at 0.05 level since 0.924 , z-test is not significant at 0.05 level since 0.92 is greater than 0.05 . This means that there is no 
significant difference in the rating of male and female business education teachers on the problem that hinders the effective utilization of ICTs in the teaching and learning of business education courses in the Nigerian universities. Therefore, the null hypothesis is accepted.

\section{DISCUSSIONS}

This study revealed that the inclusion of the ICTs in the teaching and learning of business education courses in Nigerian universities have affected the utilization of ICT due to global changes. Business educators agreed that some strategies could be used to ensure effective utilization and application of ICT in teaching/learning of business education courses as to enhance the quality of the programme; such as teachers enhance salaries, adequate power supply, government funding and procurement for ICT tools, government intervention into ICT school curriculum, provision of ICT tools, facilities and infrastructure, provision of enough computers, etc. the findings are in line with the opinion of Mandara (2012) that the provision of the technical support, huge amount of capital for the purchasing of equipment/facilities, appropriate textbooks encourages and motivates of business education teachers and students enhances the teaching and learning of various business education courses. Though, these teachers seem not to be motivated in one item.

This study found that ICT tools/facilities as identified by business educators were not properly utilized in delivering of business education courses. In support of the above view, Pelgum (2001) states that the obstacles for ICT implementation include the following: difficult to integrate ICT to instruction, insufficient teacher's time, not enough simultaneous access, poor internet connection, scheduling of computer time, poor peripherals, teachers lack of ICT knowledge/skills, lack of technical personnel etc.

The findings also reveals that business educators agree that some problems hinders the effective utilization of ICT in delivering business educations courses, these include; limited equipment, inadequate skills, time constrains, power supply, inadequate lines, management attitude and the teacher's own lack of interest/knowledge about computer (Pelgrum, 2001, Lewis and Smith, Smith 2002, and Kwacha, 2001). The result 
therefore agrees with the above findings that there is lack of proper funding of vocational education of which business education is inclusive. (Aigbepue, 2011).

\section{Conclusion}

The findings of the study showed that there was no significant difference in the mean scores of business education teachers irrespective of their gender. So the result indicate that due to non-availability of ICT tools/facilities, business teachers were unable to make effective use of the ICT tools in delivering business education courses, therefore, resulting to low skilled teachers and students which is the negative objective of ICTs. Hence, a competent teacher masters his/her subject matter.

\section{Recommendation}

The following steps would be adopted in proffering solutions to the problems of utilizing ICT in business education:

1. The Nigerian government should address the issue of incessant supply of electric powers.

2. Government should provide huge sum of money for the procurement of ICT tools/facilities.

3. The philanthropist should in collaboration with the school provide ICTs tools, ICT centers and donation of funds.

4. Teachers should be adequately exposed to ICT training for acquisitions of competent to enable them retain the skills and knowledge.

5. Teachers' conditions of service should be enhanced and incentives improved.

6. Government should be involved in developing and training of ICT experts who will work in partnership with educators and teachers.

7. There should be inclusion of ICT by the Nigerian government in school curriculum especially in the teacher education curriculum.

8. ABEN should form a global curriculum for ICT and business education programme so that the recipients in all the tertiary institutions will cover the same curriculum with their counterparts. 


\section{References}

Agbepue, S. (2011).The Role of Vocational Education and Information Technology towards Poverty Reduction and Inhibiting Factors to Poverty Alleviation. JORIND (9) June, 2011. www.Transcampus .Org/Journals. Retrieved 30 ${ }^{\text {th }}$, August, 2012.

Alibi, E. (2004, April 30). Evolving Role of ICT in Teaching, Research, and

Publishing. Nigerian Tribune, 30-31

Anao, A.R. (1986). The Role of Business Education in Developing Economy.Business Education Journal. (1) 19 -24

Egungu, E. (2001) in Nzotta, S.M. (2002). Human Resources Conceptual Framework, Owerri: Olliverson Ind. Publishers.

Federal Government of Nigeria (2004). .National Policy on Education. Lagos: National Educational Research and Development Center.

Hawkins, R.J (1998). Ten Lessons for ICT and Education In Developing World Banks Development Indicators, World Bank, New York: Dover

Kwacha, P.Z. (2001). The Imperative of Information and Communication Technology for Technology in Nigeria. MOFLOT Journal of Online Learning and Technology, 3 (4), 10-15

Koonz, H.O. And Weihirich, H. (1990).Management Tokyo McGraw Hill Book Company

Law, B and Smith, R. (2002). The Development of An Electronic Education Portfolio: An Outline for Medical Education Professional. Teaching and Learning In Medicine, 19 (2), 139 147 
Law, N. Pelgrum, W.I and Plomp, J. (2008).Pedagogy and ICT Use in Schools around the World: Findings from The IFA SITES 2006 Study. Hong Kong: Springer

Mandara, B. (2012). Utilization of Information and Communication Technologies (ICT) in the Teaching of Office Education Graduates in Adamawa State Tertiary Institutions. Journal of Education and Policy Review, 4 (1), 1-9

Nwosu, O and Ogbomo, E.F. (2012). ICT in Education: A Catalyst for Effective Use of Information. PNLA Quarterly: The Official Publication of the Pacific North West Library Association.

Nzotta, S.M. (2002). Human Resources Management: Conceptual Framework. Owerri: Olliverson Ind. Publishers.

Odiari, A.U. (1997). Management Information System: Principles and Design. Enugu: Glanic Venture, Pelgrum, W.I. (2001). Obstacles to the Integration of ICT in Education: Results From A World Wide Educational Assessment. Computer and Education, 163 178

Sadker, M.P and Sader, D.M. (2003).Teachers' School and Society .New York: Megraw Hill 